\title{
FOREIGN PORTFOLIO INVESTMENT INFLOWS AND ECONOMIC PERFORMANCE IN MALAYSIA A Disaggregated Analysis
}

\author{
Jarita Duasa \\ Salina H. Kassim
}

Based on disaggregated data, this study empirically examines the importance of foreign portfolio investment (FPI) to the Malaysian economic performance. The study adopts the vector error correction model to analyze the relationships between FPI inflows from major investing countries, namely the United States, the United Kingdom, Singapore and Hong Kong and Malaysia's real GDP using quarterly data covering the period from Q1:1991 to Q3:2007. For further inferences, this study adopts an innovation accounting by simulating variance decompositions and impulse response functions. This study finds that there is a significant positive association between Malaysia's GDP and U.K.'s FPI inflow, particularly in the long run.

Keywords: economic performance; foreign portfolio investment; impulse response function; variance decomposition; VECM

JEL classifications: G15, C32, C12 
Gadjah Mada International Journal of Business, September - December 2008, Vol. 10, No. 3

\section{Introduction}

The relationship between foreign portfolio investment (FPI) and a country's economic performance remains a subject of intense debate among researchers and policymakers. Proponents of capital market integration generally point to the virtues of FPI that promotes economic growth such as promoting the development of host country's financial market and providing easy access to financing for the local deficit units. Among others, La Porta et al. (2000) and Bekaert and Harvey (2003) highlight that an increase in liquidity due to a greater inflow of FPI in the capital market results in an easier access to financing at lower cost of capital, which is crucial to support economic activities. The inflow of FPI into the local stock markets helps alleviate financial constraints of firms (Laeven 2003; Knill 2004; Beck et al. 2005). Better access to financing provided by the free flow of portfolio investments contributes to efficient allocation of capital and thus greater economic outputs (Wurgler 2000; Love 2003; Rajan and Zingales 1998). In short, FPI contributes positively to the economic growth of the host country. At the financial market level, increased FPI inflows result in a further development of the capital market, since the greater liquidity means a deeper and broader market (Levine and Zervos 1996). Studies by Patro and Wald (2005) and Kim and Singal (2000) relate FPI to the domestic stock markets, and document favorable contribution of FPI to support- ing the domestic stock markets. At the consumption level, the multiplier effect further propagates the impact of growth in the stock market through the wealth effects. In this regard, capital flows act as a catalyst to economic growth and contributetoward increased wealth creation. Due to the several virtues of capital market integration, there is competition among countries to create positive "pull" factors to attract foreign investment. As a result, host countries would undertake higher industry standards and better regulations, improve corporate governance and business transparency, resulting in greater investor protection and thereby increasing investor confidence (Feldman and Kumar 1995; Shinn 2000).

Despite the rich literature on the virtues of cross-border capital flows, critics highlight that the potentially damaging aspects of FPI are rooted in its short-term and volatile in nature (see for example, Baghwati1998; Boyd and Smith 1992). The volatility of FPI has often been quoted as the major reason behind financial market distress, leading to financial crisis. Large and abrupt reversal of portfolio investment is often associated with financial market panics since it is taken as a manifestation of impending financial crisis (Knill 2004; Sula and Willet 2006). More importantly, as highlighted by Henry (2003) and DemirgucKunt and Detragiache (1999) based on experiences of many countries faced with financial crises, the volatility of portfolio investment further exacer- 
bates the impact of a financial crisis. Foreign portfolio instability complicates the implementation of macroeconomic stabilization policies by the policymakers. Uncertainties in the flow of FPI result in unpredictable impacts on money supply, exchange rate level and stock market volatility (Patro and Wald 2005). In particular, sustained periods of excessive capital inflows due to high capital mobility could result in the formation of asset price bubbles, thus sparking inflationary pressure. Sudden withdrawal in portfolio investment accompanied by major correction in asset prices may pose risk to the economy (Bank Negara Malaysia 2006).

This study seeks to analyze FPI in the Malaysian case, and provides recent empirical evidence of whether the FPI brings benefits to the Malaysian economy. Based on the above-mentioned literature, it is hypothesized that FPI inflows will contribute positively to Malaysian economic growth. While research analyzing the relationship between FPI and the Malaysian economic performance are abundant, these studies have been analyzing the total or aggregate FPI data. An area of novelty of this study is that it analyzes FPI data in Malaysia based on the country of origin. This disaggregated or country-by-country analysis enables detailed inferences to be made with respect to the investment behavior of the major investing countries in Malaysia. Thus, it is also hypothesized in this study that each FPI inflow from developed countries contributes positively and significantly to Malaysia's economic growth. In this regard, the findings may provide a new perspective on the analysis of the characteristics of FPI and its impact on the Malaysian economy.

The rest of the paper is organized as follows: the next section provides some background information on FPI based on the Malaysian experience. In particular, this section highlights investment behavior from the largest four investing countries in Malaysia. Section 3 presents the empirical methods and preliminary analysis of the data. Section 4 highlights the empirical findings, including the data preliminaries and the results based on the unrestricted VAR and VECM tests. Further inferences are then made based on the VDC and IRF analyses. Finally, section 5 concludes and draws several policy recommendations from the major findings of the paper.

\section{Foreign Portfolio Investment in Malaysia}

During the period of 1991-2007, inflows of FPI into Malaysia have been substantial and rather volatile. The amount of total FPI inflows ranged from RM19.3 billion in 1991 to a historical high of RM376.4 billion in 2007 (Table 1). Inflows of FPI have been very volatile in the pre-1997 period but have become more stable in the post-1997/1998 Asian crisis period. For example, in 1994-1997 period, inflows of FPI reached a high of RM238.4 billion, which was higher 
Gadjah Mada International Journal of Business, September - December 2008, Vol. 10, No. 3

than the nominal GDP during the year at RM195.5 billion. Following the crisis in mid-1997, inflows of FPI declined substantially to RM57 billion in 1998 and reached a low of RM37.9 billion in 2001. Thereafter, there seemed to be a stable increase in FPI inflows, and the inflows reached a record high of RM376.4 billion in 2007.

In comparing inflows and outflows, net portfolio investment recorded the largest negative flow dur- ing the crisis in 1997 at RM28.4 billion and deficits were frequent in the years following the crisis. However, since 2003, Malaysia continues to record FPI surpluses, except for the small deficit in 2005. In particular, Malaysia recorded a positive net FPI amounting to RM23.8 billion in 2007 in view of the record high inflow of FPI during the year.

Of total FPI into Malaysia, ap-

Table 1.Total Foreign Portfolio Investment in Malaysia, 1991-2007 (in RM Million)

\begin{tabular}{|c|c|c|c|c|}
\hline & $\begin{array}{c}\text { Nominal } \\
\text { GDP }\end{array}$ & $\begin{array}{c}\text { Total } \\
\text { FPI Inflow }\end{array}$ & $\begin{array}{c}\text { Total } \\
\text { FPI Outflow }\end{array}$ & Net \\
\hline 1991 & 135,123 & 19,346 & 21,274 & $-1,928$ \\
\hline 1992 & 150,681 & 60,935 & 53,043 & 7,892 \\
\hline 1993 & 172,193 & 187,779 & 162,128 & 25,651 \\
\hline 1994 & 195,460 & 238,454 & 224,425 & 14,029 \\
\hline 1995 & 222,472 & 106,414 & 101,054 & 5,360 \\
\hline 1996 & 253,732 & 144,933 & 136,090 & 8,843 \\
\hline 1997 & 281,889 & 156,162 & 184,517 & $-28,355$ \\
\hline 1998 & 284,474 & 57,028 & 58,286 & $-1,258$ \\
\hline 1999 & 299,193 & 43,598 & 42,532 & 1,066 \\
\hline 2000 & 356,401 & 54,529 & 63,274 & $-8,745$ \\
\hline 2001 & 352,579 & 37,910 & 39,891 & $-1,981$ \\
\hline 2002 & 383,212 & 54,383 & 59,381 & $-4,998$ \\
\hline 2003 & 418,769 & 76,013 & 65,164 & 10,849 \\
\hline 2004 & 474,049 & 135,107 & 100,419 & 34,688 \\
\hline 2005 & 519,451 & 127,298 & 134,137 & $-6,839$ \\
\hline 2006 & 572,555 & 172,661 & 161,579 & 11,082 \\
\hline 2007 & 641,864 & 376,444 & 352,612 & 23,832 \\
\hline Average & 336,123 & 120,529 & 115,283 & 5,246 \\
\hline
\end{tabular}


Duasa \& Kassim-Foreign Portfolio Investment Inflows and Economic Performance in Malaysia

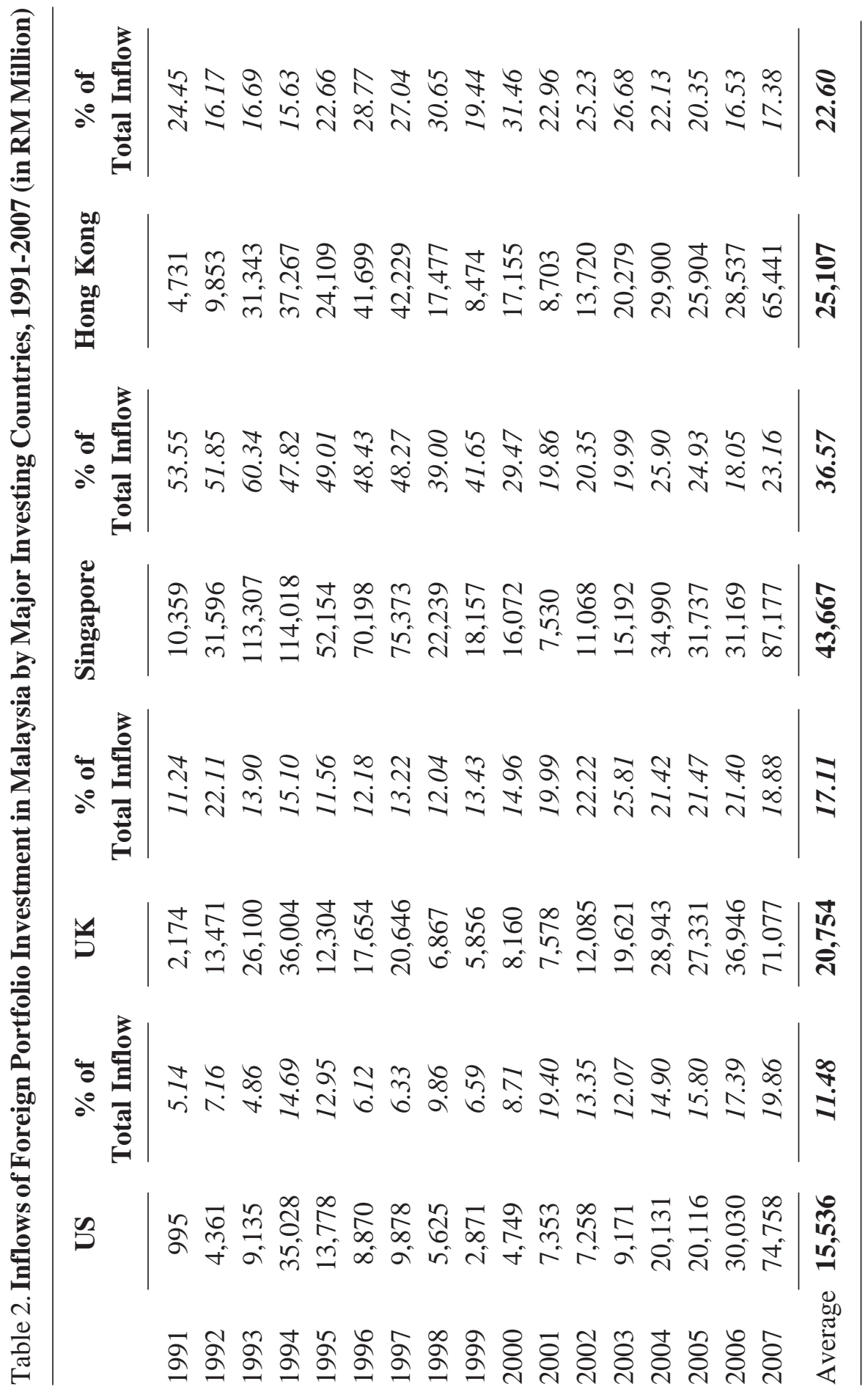


proximately 80 percent originated from four countries, namely the U.S., the U.K., Singapore and Hong Kong. On average, in the 1991-2007 period, 11.5 percent of total FPI came from the U.S., 17.1 percent from the U.K., 36.6 percent from Singapore and 22.6 percent from Hong Kong. An interesting observation of FPI from these countries is that the share of FPI inflows from these countries has continued to decline. In particular, in 1991, around 94.4 percent of total FPI came from these countries, while in 2007, the share has dropped significantly to only 79.3 percent. The decline was contributed by lower FPI from Singapore (from 53.5 percent in 1991 to 23.2 percent in 2007) and Hong Kong (from 24.4 percent in 1991 to 17.4 percent in 2007). The contribution of FPI from the U.S. has increased from 5.1 percent in 1991 to 20 percent in 2007, while that from the U.K. has also increased from around 15 percent in the 1990 s to around 22 percent in the post2000 period. On aggregate basis, the decline in the contribution of these countries to total FPI inflows also indicate the increasing importance of FPI from other sources such as from "other countries" whose details are not specified by the Malaysian central bank Bank Negara Malaysia.

\section{Methodology}

Data of FPI inflows from the U.S., the U.K., Singapore and Hong Kong as well as Malaysian real GDP are quarterly, ranging from Q1: 1991 to
Q3:2007 and are sourced from Bank Negara Malaysia's Monthly Statistical Bulletin of various issues. The raw data obtained for all variables are in RM million and the base year for real GDP is 1987. All variables are expressed in their logarithmic transformation, denoted by small letters. $\Delta$ denotes the first difference operator.

To evaluate the integration properties of the variables, we employ the standard augmented Dickey-Fuller (ADF) and Phillips-Perron (PP) tests (Dickey and Fuller 1979; Phillips and Perron 1988). A variable is said to be integrated of order d, written $I(\mathrm{~d})$ if it requires differencing d times to achieve stationarity. For cointegration, we employ the VAR based tests of Johansen (1988) and Johansen and Juselius (1990).

In examining the importance of FPI inflows from these foreign countries to Malaysian economic performance, the VAR model is applied for all FPI inflows and Malaysian real GDP. In this analysis, therefore, there is a set of $\mathrm{p}=5$ endogenous variables, $\mathrm{z}$ $=$ [rgdp, fpiius, fpiiuk, fpiis, fpiihk]. Following Johansen $(1988,1991)$ and Johansen and Juselius (1990, 1992), we consider a $p$-dimensional vector time series $z t$ and model it as an Unrestricted Vector Autoregression(VAR) involving up to $k$-lags of $z_{t}$.

$$
\begin{aligned}
\mathrm{z}_{\mathrm{t}}= & \mathrm{A}_{1} \mathrm{z}_{\mathrm{t}-1}+\ldots+\mathrm{A}_{\mathrm{k}} \mathrm{z}_{\mathrm{t}-\mathrm{k}}+\mu+\varepsilon_{\mathrm{t}}, \\
& \varepsilon_{\mathrm{t}} \sim \operatorname{niid}(0, \Sigma)
\end{aligned}
$$

where $z_{t}$ is a $(p \times 1)$ matrix and each of the $A_{i}$ is a $(p \times p)$ matrix of parameters. 
The Johansen approach is used with the consideration that it enables hypotheses testing concerning the matrix and the number of equilibrium relationships to be carried out.

Before test of cointegration could be done, we have to choose the maximum lag length, $k$, in the Unrestricted VAR. Choosing the appropriate lag length is important since a $k$ too small will invalidate the tests whereas a $k$ too large may result in a loss of power (Kanioura 2001). The appropriate lag is chosen by checking the residuals of VAR model with one lag after another and the selection of lag is based on the one that has the absence of serial correlation in the residuals.

Being aware of the lag order, then we construct the long-run equations (Unrestricted VAR model) for the series. The analysis is carried out further by doing the Johansen cointegration test with $k-1$ lag. The determination of the number of cointegrating vectors is based on the Maximum Eigenvalue and the Trace tests.

The vector error correction model (VECM) restricts the long-run behavior of the endogenous variables to converge to their cointegrating relationships while allowing for short-run adjustment dynamics. In this case, the cointegration terms are the correction terms since a series of partial short-run adjustments correct gradually the deviation from long-run equilibrium. The VECM corresponds to a restricted VAR of order $k-1$ for the first differenced series, with the inclusion of error-correction terms for the cointegrating vectors. We write a $p$ dimensional VECM as follows:

$$
\begin{gathered}
\Delta \mathrm{y}_{\mathrm{t}}=\sum_{\mathrm{i}}^{\mathrm{k}-1} \Gamma \Delta \mathrm{y}_{\mathrm{t}-1}+\Pi \mathrm{y}_{\mathrm{t}-1}+\mu+\varepsilon_{\mathrm{t}}, \\
\mathrm{t}=1, \ldots \mathrm{T}
\end{gathered}
$$

where $y_{t}$ is the set of $I(1)$ variables discuss above; $\varepsilon_{t} \sim$ niid $(0, \Sigma) ; \mu$ is a drift parameter, and $\Pi$ is a $(p \times p)$ matrix of the form $\Pi=\alpha \beta^{\prime}$ where a and $\beta$ are both $(p \times r)$ matrices of full rank, with $\beta$ containing the $r$ cointegrating vectors and carrying the corresponding loadings in each of the $r$ vectors. The adjustment coefficients in matrix $\alpha$ refer to the coefficients of the Error Correction (ECM) terms.

Additionally, we adopt an innovation accounting by simulating variance decompositions (VDCs) and impulse response functions (IRFs) for further inferences. VDC and IRF serve as a tool for evaluating the dynamic interactions and strength of causal relations among variables in the system. The VDC indicates the percentage of a variable's forecast error variance attributable to its own innovations and innovations in other variables. Thus, from the VDC, we can measure the relative importance of fluctuation in one country's FPI inflow in accounting for fluctuation in FPI inflows from other countries. Moreover, the IRF traces the directional responses of a variable to a one standard deviation shock of another variable. This means that we can observe the direction, magnitude and persistence of FPI inflow of 
each country toward variation in Malaysian real GDP.

\section{Findings}

As a preliminary step, we first subject each series/variable to Augmented Dickey Fuller (ADF) and Phillip-Perron (P/P) unit root tests. The results of the tests are displayed in Table 3 . The results generally suggest that most variables are integrated of order one as the null hypothesis that the series are not stationary is accepted at level but rejected at first difference. In other words, the variables are stationary at first difference or I(1).

For this model, the maximum lag length, $k$, of 6 is chosen. Based on cointegration tests, Maximum Eigenvalue statistic suggests one cointegrating vector, and Trace statistic suggests

Table 3. Unit Root Tests Results

\begin{tabular}{|c|c|c|c|c|}
\hline \multirow[t]{2}{*}{ Variable } & \multicolumn{2}{|c|}{$\begin{array}{c}\text { ADF test statistic } \\
\text { (with trend and intercept) }\end{array}$} & \multicolumn{2}{|c|}{$\begin{array}{c}\text { P/P test statistic } \\
\text { (with trend and intercept) }\end{array}$} \\
\hline & Level & $\begin{array}{c}\text { First } \\
\text { Difference }\end{array}$ & Level & $\begin{array}{c}\text { First } \\
\text { Difference }\end{array}$ \\
\hline rgdp & -2.44 & $-3.71 * *$ & $-3.34 *$ & $-9.48 * * *$ \\
\hline fpiius & $-3.40 *$ & $-10.52 * * *$ & $-3.33 *$ & $-10.77 * * *$ \\
\hline fpiiuk & $-3.47 *$ & $-10.83 * * *$ & $-3.46 *$ & $-10.69 * * *$ \\
\hline fpiis & -2.71 & $-7.92 * * *$ & -2.69 & $-7.87 * * *$ \\
\hline fpiihk & -2.97 & $-6.96 * * *$ & -2.97 & $-6.83 * * *$ \\
\hline
\end{tabular}

Note: $* * *, * *$ and $*$ denote significant at 1 percent, 5 percent and 10 percent levels, respectively.

Table 4. Johansen Cointegration Tests Results

\begin{tabular}{|c|c|c|c|c|}
\hline $\begin{array}{l}\text { Null Hypothesis } \\
\text { about Rank (r) }\end{array}$ & $\begin{array}{l}\text { Max-Eigen } \\
\text { Statistic }\end{array}$ & $\begin{array}{l}5 \% \text { Critical } \\
\text { Value }\end{array}$ & $\begin{array}{c}\text { Trace } \\
\text { Statistic }\end{array}$ & $\begin{array}{l}\text { 5\% Critical } \\
\text { Value }\end{array}$ \\
\hline$r=0$ & 36.04 & 33.88 & 90.21 & 69.82 \\
\hline$r \leq 1$ & 27.58 & 27.58 & 54.17 & 47.86 \\
\hline$r \leq 2$ & 15.24 & 21.13 & 26.59 & 29.79 \\
\hline$r \leq 3$ & 11.01 & 14.26 & 11.3 & 15.49 \\
\hline$r \leq 4$ & 0.34 & 3.84 & 0.34 & 3.84 \\
\hline
\end{tabular}


Duasa \& Kassim-Foreign Portfolio Investment Inflows and Economic Performance in Malaysia

two cointegrating vectors that exist among the variables. Table 4 provides detailed results of these cointegration tests. We decide to select only one cointegrating vector based on Maximum Eigenvalue test.
Normalizing rgdp for cointegrating vector 1 , following is the suggested vector:

$\mathrm{CV} 1=$ rgdp +3.23 fpiihk -1.94 fpiis +7.91 fpiiuk - 7.38fpiius

Table 5. The Vector Error Correction Model Results

\begin{tabular}{|c|c|c|c|}
\hline $\begin{array}{l}\text { Independent } \\
\text { Variable }\end{array}$ & $\begin{array}{c}\text { Dependent } \\
\text { Variable:rgdp }\end{array}$ & $\begin{array}{l}\text { Independent } \\
\text { Variable }\end{array}$ & $\begin{array}{c}\text { Dependent } \\
\text { Variable:rgdp }\end{array}$ \\
\hline constant & $0.013 * *$ & $\Delta$ fpiis $_{t-2}$ & 0.006 \\
\hline$\Delta g d p_{t-1}$ & 0.103 & $\Delta$ fpiis $_{t-3}$ & 0.012 \\
\hline$\Delta g d p_{t-2}$ & -0.246 & $\Delta$ fpiis $_{t-4}$ & 0.017 \\
\hline$\Delta g d p_{t-3}$ & -0.106 & $\Delta$ fpiis $_{t-5}$ & $0.025 *$ \\
\hline$\Delta g d p_{t-4}$ & $0.582 * * *$ & $\Delta f p i i s_{t-6}$ & 0.014 \\
\hline$\Delta g d p_{t-5}$ & -0.242 & $\Delta$ fpiihk $_{t-1}$ & -0.004 \\
\hline$\Delta g d p_{t-6}$ & -0.097 & $\Delta$ fpiihk $_{t-2}$ & -0.005 \\
\hline$\Delta$ fpiius $_{t-1}$ & $-0.028 *$ & $\Delta$ fpiihk $_{t-3}$ & 0.005 \\
\hline$\Delta$ fpiius $_{t-2}$ & $-0.035 * *$ & $\Delta$ fpiihk $_{t-4}$ & $-0.019 *$ \\
\hline$\Delta$ fpiius $_{t-3}$ & -0.008 & $\Delta$ fpiihk $_{t-5}$ & 0.007 \\
\hline$\Delta$ fpiius $_{t-4}$ & -0.005 & $\Delta$ fpiihk $_{t-6}$ & -0.004 \\
\hline$\Delta$ fpiius $_{t-5}$ & 0.003 & $C V 1_{t-1}$ & $-0.006 * * *$ \\
\hline$\Delta$ fpiius $_{t-6}$ & 0.005 & & \\
\hline$\Delta$ fpiiuk $_{t-1}$ & $0.052 * *$ & observation & 60 \\
\hline$\Delta$ fpiiuk $_{t-2}$ & $0.048 * *$ & Adiusted $R^{2}$ & 0.77 \\
\hline$\Delta$ fpiiuk $_{t-3}$ & 0.022 & Aajustea $\mathrm{K}^{-}$ & $0.1 /$ \\
\hline$\Delta$ fpiiuk $_{t-4}$ & 0.019 & F-statistic & $7.24 * * *$ \\
\hline$\Delta$ fpiiuk $_{t-5}$ & -0.009 & Diagnostic test: & \\
\hline$\Delta$ fpiiuk $_{t-6}$ & -0.009 & Far & 0.015 \\
\hline \multirow{2}{*}{$\Delta$ fpiis $_{t-1}$} & 0.001 & Farch & 0.046 \\
\hline & & JBnormal & 2.712 \\
\hline
\end{tabular}

Notes: 1. Far is the F-statistic of Breusch-Godfrey Serial Correlation LM Test. Farch is the F-statistic of ARCH Test.

JBnormal is the Jarque-Bera Statistic of Normality Test.

2. ${ }^{* * *},{ }^{* *}$ and $*$ denote significant at $1 \%, 5 \%$ and $10 \%$ levels, respectively. 
We then proceed with an estimated error correction model to illustrate how the cointegration results might be utilized. The VECM restricts the long-run behavior of the endogenous variables to converge to their cointegrating relationships while allowing for short-run adjustment dynamics. Table 5 displays the short-run equation. All coefficients in the shortrun equation are coefficients relating to the short-run dynamics of the model's convergence to equilibrium, and coefficient on lag $C V$ (error correction term) represent the speed of adjustment. The error correction term $\left(\mathrm{CV} 1_{\mathrm{t}-1)}\right.$ in the equation is significant with a negative sign. The significant error correction term shows the evi- dence of causality in at least one direction. The significant coefficient on $\Delta r g d p_{t-4}$ with a positive sign indicates that in the short run, previous fourth quarter of real GDP affects present quarter of real GDP positively. Significant and positive coefficients on $\Delta$ fpiiuk $_{t-1}$ and $\Delta$ fpiiuk $_{t-2}$ also indicate the importance of U.K. capital inflows to Malaysian real GDP in short run. Similar contribution made by FPI from Singapore as the coefficient on $\Delta$ fpiis ${ }_{5}$ is positive and significant even though only at 10 percent level. Although few FPI variables of the U.S. and Hong Kong are significant, but their negative signs reflect their opposite contributions to the Malaysian economic growth in short run.

Table 6. Variance Decompositions

\begin{tabular}{|c|c|c|c|c|c|c|}
\hline \multicolumn{7}{|c|}{ Variance Decomposition of $r g d p$} \\
\hline $\begin{array}{l}\text { Period } \\
\text { (Qtr) }\end{array}$ & S.E. & rgdp & fpiihk & fpiis & fpiiuk & fpiius \\
\hline 2 & 0.028765 & 75.49872 & 4.279186 & 14.65673 & 4.179026 & 1.386342 \\
\hline 4 & 0.039371 & 51.65426 & 2.352223 & 23.31562 & 18.97908 & 3.698821 \\
\hline 6 & 0.051678 & 40.03162 & 1.381554 & 22.58055 & 23.47356 & 12.53272 \\
\hline 8 & 0.059424 & 30.55622 & 2.478418 & 18.12536 & 33.85309 & 14.98691 \\
\hline 10 & 0.066364 & 28.02165 & 2.382579 & 15.71447 & 39.33902 & 14.54228 \\
\hline 12 & 0.073317 & 23.13764 & 2.065679 & 13.21255 & 48.36033 & 13.22380 \\
\hline 14 & 0.082642 & 22.07499 & 4.973116 & 12.77929 & 49.66925 & 10.50335 \\
\hline 16 & 0.089834 & 20.15218 & 5.755988 & 12.73269 & 52.29387 & 9.065275 \\
\hline 18 & 0.096188 & 20.83634 & 5.753348 & 12.56133 & 52.83310 & 8.015880 \\
\hline 20 & 0.099602 & 19.97484 & 5.419326 & 11.83191 & 54.81468 & 7.959239 \\
\hline
\end{tabular}


Duasa \& Kassim-Foreign Portfolio Investment Inflows and Economic Performance in Malaysia

Figure 1. Impulse Response Functions
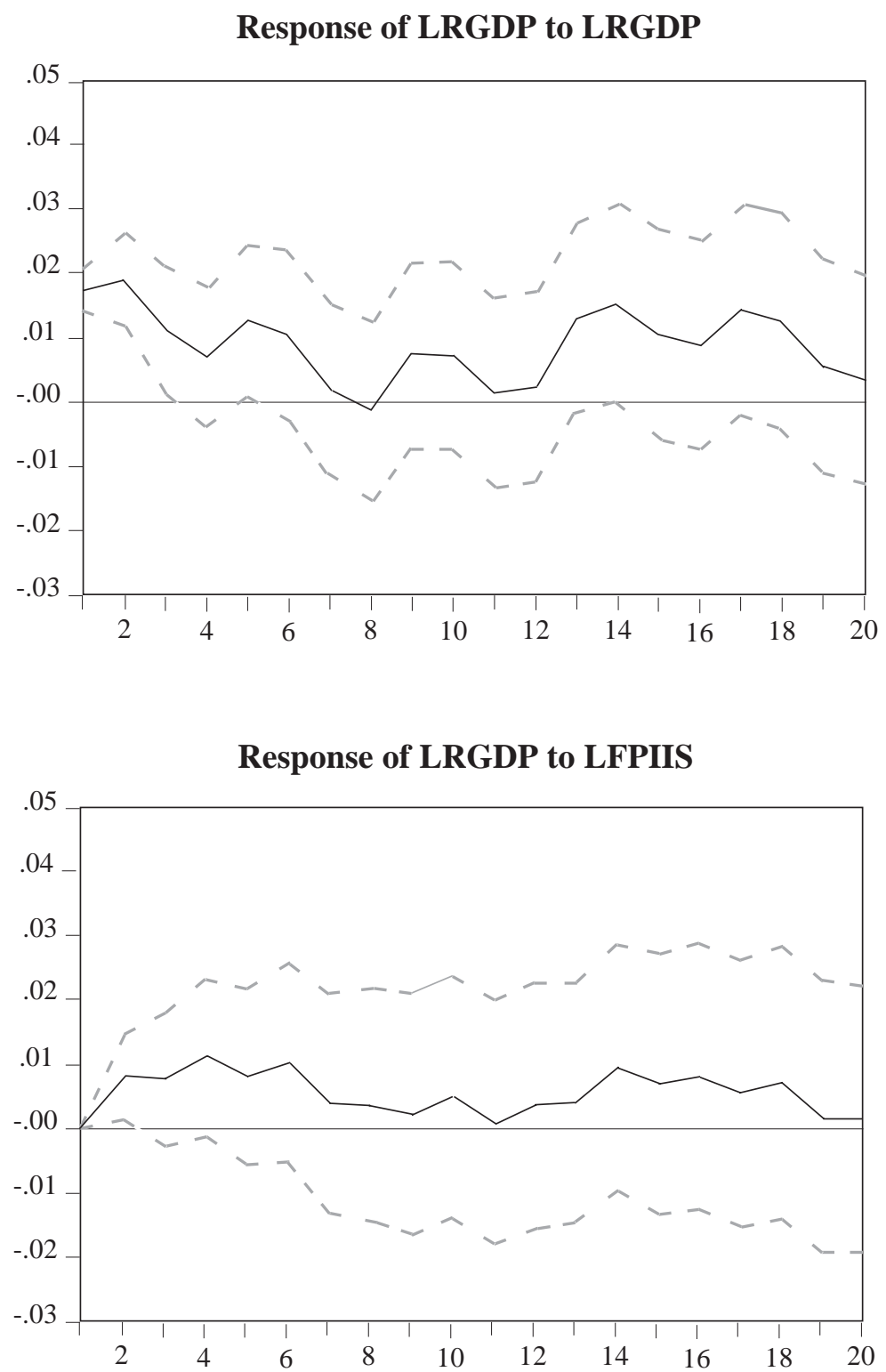
Gadjah Mada International Journal of Business, September - December 2008, Vol. 10, No. 3

\section{Continued from Figure 1}
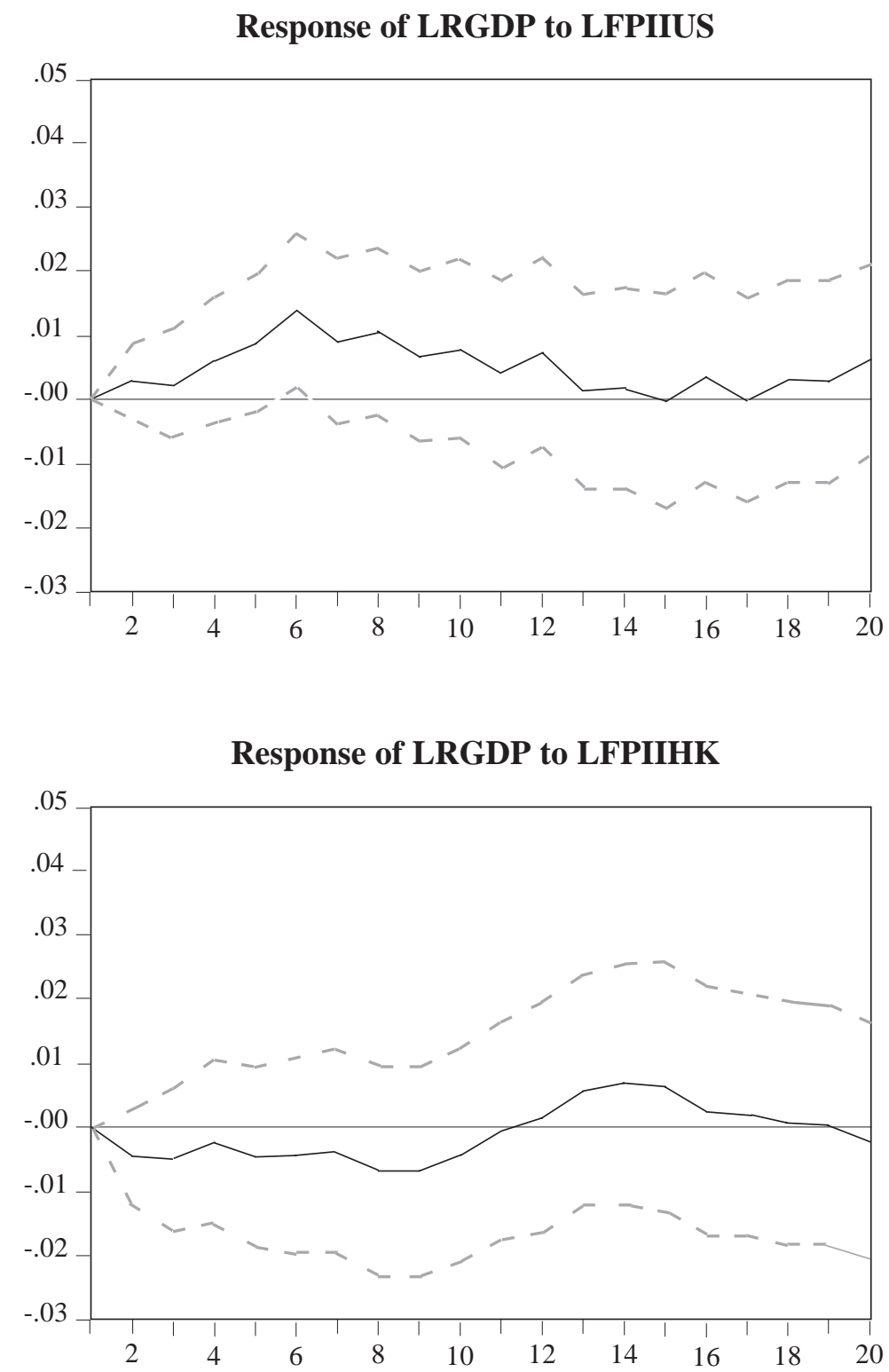
Duasa \& Kassim-Foreign Portfolio Investment Inflows and Economic Performance in Malaysia

\section{Continued from Figure 1}

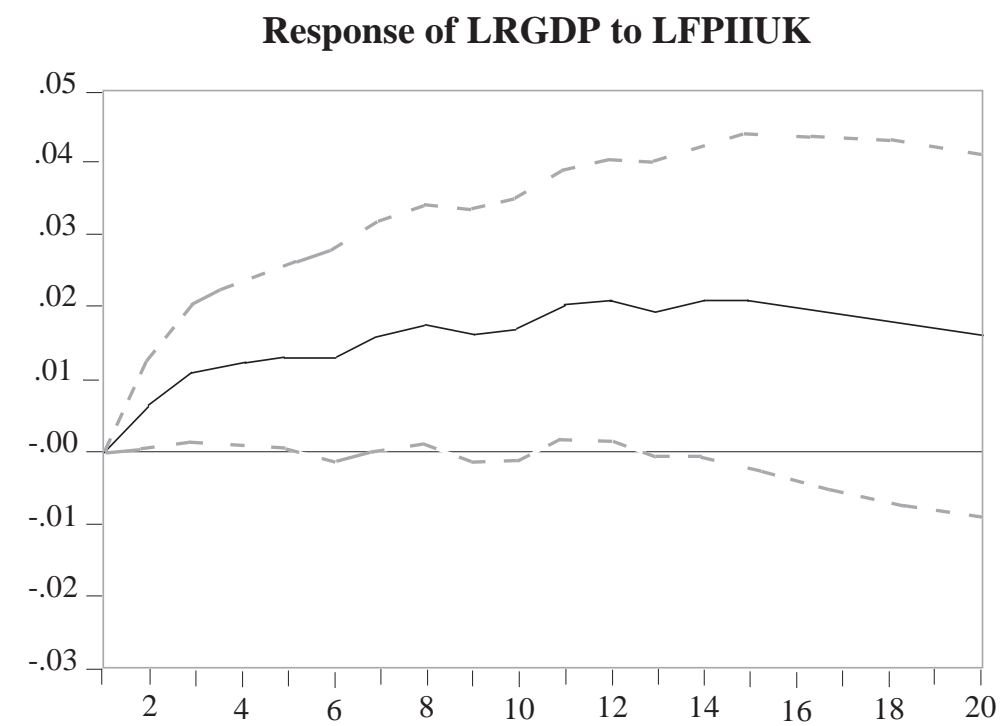

Table 6. Variance Decompositions

\begin{tabular}{|c|c|c|c|c|c|c|}
\hline \multicolumn{7}{|c|}{ Variance Decomposition of $r g d p$} \\
\hline $\begin{array}{c}\text { Period } \\
\text { (Qtr) }\end{array}$ & S.E. & rgdp & fpiihk & fpiis & fpiiuk & fpiius \\
\hline 2 & 0.028765 & 75.49872 & 4.279186 & 14.65673 & 4.179026 & 1.386342 \\
\hline 4 & 0.039371 & 51.65426 & 2.352223 & 23.31562 & 18.97908 & 3.698821 \\
\hline 6 & 0.051678 & 40.03162 & 1.381554 & 22.58055 & 23.47356 & 12.53272 \\
\hline 8 & 0.059424 & 30.55622 & 2.478418 & 18.12536 & 33.85309 & 14.98691 \\
\hline 10 & 0.066364 & 28.02165 & 2.382579 & 15.71447 & 39.33902 & 14.54228 \\
\hline 12 & 0.073317 & 23.13764 & 2.065679 & 13.21255 & 48.36033 & 13.22380 \\
\hline 14 & 0.082642 & 22.07499 & 4.973116 & 12.77929 & 49.66925 & 10.50335 \\
\hline 16 & 0.089834 & 20.15218 & 5.755988 & 12.73269 & 52.29387 & 9.065275 \\
\hline 18 & 0.096188 & 20.83634 & 5.753348 & 12.56133 & 52.83310 & 8.015880 \\
\hline 20 & 0.099602 & 19.97484 & 5.419326 & 11.83191 & 54.81468 & 7.959239 \\
\hline
\end{tabular}


A number of diagnostic tests are conducted on the error correction model. We find no evidence of serial correlation and ARCH(Autoregressive Conditional Heteroskedasticity) effect in the disturbances. The model also passes the Jarque-Bera normality test that suggests that the errors are normally distributed.

From an estimated VAR, we compute VDCs and IRFs, which serve as tools for evaluating the dynamic interactions and strength of causal relations among the variables in the system. The results of the VDCs and IRFs are displayed in Table 6 and Figure 1, respectively.

From Figure 1, the IRF shows that real GDP does react significantly to U.K. FPI inflow innovation from three quarters until 12 quarters before it subsides to zero. The positive response of real GDP to capital inflow from the U.K. in these quarters implies that FPI inflow from the U.K. is important by contributing to economic performance of the country. However, IRF illustrates lesser importance of capital inflows from other countries (Singapore, the U.S. and Hong Kong) to Malaysian economic performance as in most quarters, the response of real GDP to the innovations of the inflows are insignificant.

The VDC is an alternative method to IRF for examining the effects of shocks to the dependent variables. It determines how much of the forecast error variance for any variable in a system is explained by innovation in each explanatory variable over a series of time horizons. Usually, own series shocks explain most of the error variance although the shocks will also affect other variables in the system. From Table 6, the own series shocks of real GDP explain most of the error variance (of real GDP) only up until six quarters. Afterwards, error variance of real GDP is highly affected by shocks of other explanatory variables. This indicates that real GDP is highly endogenous. In particular, the VDC substantiates the significant role played by FPI inflow from the U.K. in accounting for fluctuations in Malaysian real GDP. At the two-quarter horizon, the fraction of Malaysian real GDP forecast error variance attributable to variation in capital inflow from the U.K. is only about four percent, but then it increases sharply to almost 19 percent within the two-quarter period and keeps increasing to 55 percent in quarter 20 as compared to contribution from other countries' inflows. The second contributor to the forecast error variance of real GDP is FPI inflow from Singapore. The percentage of real GDP forecast error variance explained by innovation in FPI from Singapore is bigger than that from the U.K. in quarter 2 of 15 percent. The trend is increasing only up to quarter 6 , but then it is declining at a longer time horizon with only 12 percent at quarter 20. The percentage of Malaysian real GDP forecast variance explained by innovations in FPI from Hong Kong and the U.S. are rather small with less than 8 percent in the long run. Therefore, the VDC results are also highly 
supportive of the importance of FPI inflow from the U.K. to Malaysian economic performance.

The importance of U.K.'s FPI to Malaysian economic growth in short run and long run relies very much on its stability of inflow to Malaysia as compared to inflows from other countries. For example, from 1991 to 2007, the FPI inflow from the U.K. has been rather stable at around 17 percent of the total inflows (see Table 2). Compared to those of other countries, the inflows of Singapore and the U.S. are rather volatile, ranging from 18 percent to 60 percent of total inflows for Singapore and from five percent to 20 percent for the U.S. Large capital inflows to the country since 1980s are mostly related to external shocks, in particular in the form of changes in the foreign interest rate and foreign outputs (see Chuhan et al. 1993 and Fernandez-Arias 1996). During the period of 1991-1993 in particular, the interest differential between Malaysia and the rest of the world began to widen and at the same time, the market expected the Ringgit to appreciate as it was considered significantly undervalued. This resulted in a pronounced increase in the inflows of foreign capital in this period. Nonetheless, domestic factors such as liberalization of the capital account transactions, inflation stabilization (inflation in Malaysia was below four percent) and structural transformation of the economy are perhaps behind the remarkable inflows (see Mathieson and Rojas-Suarez 1993) from developed countries, particularly the U.K. Malaysia has also encouraged the development of its financial markets. In line with the trend of innovations in the international financial markets, Malaysia's capital markets have taken up securitization. In addition, the trend for markets will be for traditional institutional boundaries among commercial banking, investment banking and securities trading to be dismantled during the 1990s (Ye 1992).

It is no doubt that those international investors provide an extra pool of loanable funds for developing country such as Malaysia where capital is scarce. Increasing liquidity in the host country, resulted from stable capital inflows, could lower the cost of borrowing and thus raising output in the country. In fact, foreign capital allows a country to invest more than it could, and international flows of capital can temporarily help the economy adjust to various shocks, either internal (such as harvest failure) or external ones (such as big changes in commodity prices or recession in industrial countries) (Wahyudi 1990). Through this channel, Malaysia has maintained a real GDP growth between seven and nine percent since 1987. In other words, the growth has been due largely to a rapid increase in investment, with foreign capital providing an important source of financing for that investment. 
Gadjah Mada International Journal of Business, September - December 2008, Vol. 10, No. 3

\section{Conclusion}

This study empirically examines the importance of the inflows of FPI from the four major investing countries to the Malaysian economic performance. The results of the study based on several tests find consistent evidence of a significant positive association between Malaysia's GDP and U.K. FPI inflow, both in the long run and the short run. In particular, in the short run, the test results reveal the importance of U.K. and Singapore capital inflows to Malaysian real GDP. However, the results show that only FPI inflow from the U.K. contributes positively and significantly to Malaysia's economic growth in the long run. This is perhaps due to the fact that FPI inflow from the U.K. is rather stable within the period of study as compared to FPI inflows from other countries, especially in the wake of Asian financial crisis. Interestingly, the results of this study point toward negative contributions of U.S. and Hong Kong FPI inflows to the Malaysian economic growth, especially in short run. It is perceived that the negative impact of the inflows in the short run is largely contributed by the volatility of the foreign investment from these countries that might deter growth in the recipient country.

These results are further strengthened by IRF that also shows a positive and significant response of real GDP to capital inflow from the U.K., while the response of real GDP to other countries' inflows are insignificant. Similar conclusion can be made based on the VDC results, which further substantiate the significant role played by FPI inflow from the U.K. in accounting for fluctuation in Malaysian real GDP. Specifically, innovation in the capital inflow from the U.K. accounts up to 55 percent of the variation in the Malaysian real GDP.

Based on these results, it is conclusive that FPI inflows from the U.K. and to a lesser extent from Singapore are shown to contribute positively to Malaysia's economic performance. These inflows allow Malaysia to invest more than it could, and they can temporarily help the economy adjust to various shocks, internally and externally. Most importantly, they provide an important source of financing for investment in the country that boosts its economic growth ever since late 1980s. In view of this, it would be beneficial to Malaysia if preferential policy incentives can be provided to foreign portfolio investors, particularly from these two countries. It would be rather interesting if we could understand the type or composition of FPI coming from the U.K. and Singapore for the formulation of more effective and specific policy recommendations. This is an area of extension of the research that would further enrich the literature in this context. 
Duasa \& Kassim-Foreign Portfolio Investment Inflows and Economic Performance in Malaysia

\section{References}

Baghwati, J. 1998. The capital myth: the difference between trade in widgets and dollars. Foreign Affairs 77: 7-12.

Beck, T., A. Demirguc-Kunt, and V. Maksimovic. 2005. Financial and legal constraints to firm growth: does size matter? The Journal of Finance 60: 137-177.

Bekaert, G., and C. R. Harvey. 2003. Emerging markets finance. Journal of Empirical Finance 10 (1-2): 3-56.

Boyd, J. H., and B. D. Smith. 1992. Intermediation and the equilibrium allocation of investment capital: Implications for economic development. Journal of Monetary Economics 30: 409-432.

Chuhan, P., S. Classens, N. Mamingi. 1993. Equity and bond flow to Latin America and Asia: The role of external and domestic factors. World Bank PRE Working Paper No. 1160.

Demirguc-Kunt, A., and E. Detragiache. 1999. Financial liberalization and financial fragility. Proceedings of the World Bank Annual Conference on Development Economics.

Dickey, D. A., and W. F. Fuller. 1979. Distribution of the estimates for autoregressive time series with a unit root. Journal of the American Statistical Association 74: 427-431.

Feldman, R. A., and M. S. Kumar. 1995. Emerging equity markets: Growth, benefits, and policy concerns. The World Bank Research Observer 10 (2): 181-200.

Fernandez-Arias, E. 1996. The new wave of private capital inflows: Push or pull? Journal of Development Economics 48 (2): 389-418.

Henry, P. 2003. Capital-account liberalization, the cost of capital and economic growth. American Economic Review 93 (2): 91-96.

Johansen, S. 1988. Statistical analysis of cointegration vector. Journal of Economics Dynamics and Control 12: 231-254.

Johansen, S. 1991. Estimation and hypothesis testing of cointegrating vectors in Gaussian Vector Autoregressive Models. Econometrica 59 (006): 1551-1580

Johansen, S. 1998. Statistical analysis of cointegration vector. Journal of Economics Dynamics and Control 12: 231-254.

Johansen, S., and K. Juselius. 1990. Maximum likelihood estimation and inference on cointegration: With applications to the demand for money. Oxford Bulletin of Economics and Statistics 52: 169-210.

Johansen, S., and K. Juselius. 1992. Testing structural hypotheses in a multivariate cointegration analysis of the PPP and the UIP for UK. Journal of Econometrics 53: 211-244.

Kanioura, A. 2001. A cointegration analysis of US interest rates. Working Paper 3. Department of Economics, University of Sheffield.

Kim, E. H., and V. Singal. 2000. Stock market openings: Experience of emerging economies. Journal of Business 73: 25-66. 
Gadjah Mada International Journal of Business, September - December 2008, Vol. 10, No. 3

Knill, A. 2004. Can foreign portfolio investment bridge the small firm financing gap around the world? Working Paper. University of Maryland.

Laeven, L. 2003. Does financial liberalization reduce financing constraints? Financial Management 32 (1): 5-34.

La Porta, R., F. Lopez-de-Silanes, A. Shleifer, and R. Vishny. 2000. Investor protection and corporate governance. Journal of Financial Economics 58: 3-27.

Levine, R., and S. Zervos. 1996. Stock market development and long-run growth. World Bank Economic Review 10: 323-339.

Love, I. 2003. Financial development and financing constraints: international evidence from the structural investment model. Review of Financial Studies 6: 765-791.

Mathieson, D., and L. Rojas-Suarez. 1993. Liberalization of capital account: Experiences and issues. IMF Occasional Paper 103.

Patro, D. and P. Wald. 2005. Firm characteristics and the impact of emerging market liberalization. Journal of Banking and Finance 29 (7): 1671-1695.

Phillips, P. and P. Perron. 1988. Testing for a unit root time series regression. Biometrika 75 (2): 335-346.

Rajan, R., and L. Zingales. 1998. Financial dependence and growth. American Economic Review 88 (3): 559-586.

Shinn, J. 2000. Nitwits, barbarians, and the convergence cycle. Working Paper. Princeton University.

Sula, O., and T. D. Willet. 2006. Reversibility of different types of capital flows to emerging markets. Munich Personal RePEc Archive 384.

Wahyudi, B. S. 1990. International capital movements in the SEACEN countries. SEACEN Staff Papers 38.

Wurgler, J. 2000. Financial markets and the capital allocation. Journal of Financial Economics 58: 187-214.

Ye, T. 1992. Globalization of financial markets: Its impact on the SEACEN countries. SEACEN Staff Papers 43.

\section{Other References}

Bank Negara Malaysia. 2006. Financial Stability and Payment Systems Report. Kuala Lumpur.

Bank Negara Malaysia. Monthly Statistical Bulletin. Various issues. 